\title{
Cellular Toxicity Mechanisms and the Role of Autophagy in Pt(IV) Prodrug-Loaded Ultrasmall Iron Oxide Nanoparticles Used for Enhanced Drug Delivery
}

\author{
L. Gutiérrez-Romero $^{1,2}{ }^{\mathbb{D}}$, L. Rivas-García ${ }^{3} \mathbb{D}$, C. Sánchez-González $^{3} \mathbb{D}$, J. Llopis ${ }^{3} \mathbb{D}$, E. Blanco ${ }^{1,2} \mathbb{D}$ and \\ M. Montes-Bayón 1,2,*iD
}

1 Department of Physical and Analytical Chemistry, Faculty of Chemistry, University of Oviedo, C/Julián Clavería 8, 33006 Oviedo, Spain; luciaromero@uniovi.es (L.G.-R.); eblancog@uniovi.es (E.B.)

2 Instituto de Investigación Sanitaria del Principado de Asturias, (ISPA) Avda. Hospital Universitario S/N, 33011 Oviedo, Spain

3 Biomedical Research Center, Department of Physiology, Faculty of Pharmacy, University of Granada, Avda. del Conocimiento S/N, 18100 Granada, Spain; lorenrivas@ugr.es (L.R.-G.); crissg@ugr.es (C.S.-G.); jllopis@ugr.es (J.L.)

* Correspondence: montesmaria@uniovi.es

Citation: Gutiérrez-Romero, L.; Rivas-García, L.; Sánchez-González, C.; Llopis, J.; Blanco, E.; Montes-Bayón, M. Cellular Toxicity Mechanisms and the Role of

Autophagy in Pt(IV) Prodrug-Loaded Ultrasmall Iron Oxide Nanoparticles Used for Enhanced Drug Delivery. Pharmaceutics 2021, 13, 1730.

https://doi.org/10.3390/

pharmaceutics13101730

Academic Editor: Anna Angela Barba

Received: 23 July 2021

Accepted: 8 October 2021

Published: 19 October 2021

Publisher's Note: MDPI stays neutral with regard to jurisdictional claims in published maps and institutional affiliations.

Copyright: (c) 2021 by the authors. Licensee MDPI, Basel, Switzerland. This article is an open access article distributed under the terms and conditions of the Creative Commons Attribution (CC BY) license (https:// creativecommons.org/licenses/by/ $4.0 /)$.

\begin{abstract}
Ultrasmall iron oxide nanoparticles $(<10 \mathrm{~nm})$ were loaded with cis-diamminetetrachloroplatinum (IV), a cisplatin (II) prodrug, and used as an efficient nanodelivery system in cell models. To gain further insight into their behavior in ovarian cancer cells, the level of cellular incorporation as well as the platination of mitochondrial and nuclear DNA were measured using inductively coupled plasma mass spectrometry (ICP-MS) strategies. Quantitative Pt results revealed that after $24 \mathrm{~h}$ exposure to $20 \mu \mathrm{M} \mathrm{Pt}$ in the form of the $\mathrm{Pt}(\mathrm{IV})$-loaded nanoparticles, approximately $10 \%$ of the incorporated Pt was associated with nuclear DNA. This concentration increased up to $60 \%$ when cells were left to stand in drug-free media for $3 \mathrm{~h}$. These results indicated that the intracellular reducing conditions permitted the slow release of cisplatin (II) from the cisplatin (IV)-loaded nanoparticles. Similar results were obtained for the platination of mitochondrial DNA, which reached levels up to $17,400 \pm 75 \mathrm{ng} \mathrm{Pt} / \mathrm{mg}$ DNA when cells were left in drug-free media for $3 \mathrm{~h}$, proving that this organelle was also a target for the action of the released cisplatin (II). The time-dependent formation of Pt-DNA adducts could be correlated with the time-dependent decrease in cell viability. Such a decrease in cell viability was correlated with the induction of apoptosis as the main route of cell death. The formation of autophagosomes, although observed upon exposure in treated cells, does not seem to have played an important role as a means for cells to overcome nanoparticles' toxicity. Thus, the designed nanosystem demonstrated high cellular penetration and the "in situ" production of the intracellularly active cisplatin (II), which is able to induce cell death, in a sustained manner.
\end{abstract}

Keywords: nanoparticles; cisplatin prodrug; DNA; apoptosis; autophagy; mitochondria

\section{Introduction}

The use of cisplatin as an effective anticancer drug for treating various malignancies has been well-established over the years [1]. Although its antineoplastic effects were initially ascribed to its ability to generate unrepairable nuclear DNA lesions, increasing evidence also associates its mode of action with the alteration of both nuclear and cytoplasmic signaling pathways [2]. However, the positive chemotherapeutic effect of cisplatin in most cancers (e.g., ovarian, prostate, etc.) is hampered by inherent and acquired drug resistance, a multifactorial and still not well characterized process [3]. In fact, several mechanisms have been suggested to participate in conferring platinum-resistant properties to a tumor cell, such as genetic alterations in genes involved in drug uptake (and efflux), DNA repair, autophagy [4], apoptosis, and cell cycle control pathways [5]. 
Regarding drug uptake, the entrance of cisplatin inside cells is predominantly driven by the copper transport receptor 1 (CTR1) [6]. One way to circumvent incorporation through receptors like CTR1 is through the use of endocytic routes [7]. For this purpose, combinations of cisplatin (or cisplatin precursors/prodrugs) to nanostructures that permit efficient drug uptake are being widely investigated [8-10]. Among them, nanodelivery systems including liposomes or metallic nanoparticles show the capability to incorporate cisplatin (IV) prodrugs [9,11-13]. Upon entrance into the cell cytosol, the reduction of the platinum (IV) center to platinum (II) by glutathione or ascorbate occurs, resulting in the formation of functional cisplatin (II) $[14,15]$. This reaction occurs more efficiently in the reducing environment of cancer cells, increasing the selectivity of the treatment $[16,17]$.

Beside reduced intracellular incorporation, cellular resistance to cisplatin can also result from other mechanisms, including enhanced nuclear DNA repair by the nucleotide excision repair (NER) system or even evasion of cell death by apoptosis [3] or autophagy [18]. Autophagy plays a key role in the quality control of cellular components and can be induced by a number of stress conditions, including drug treatment. Recent studies have indicated that acute cisplatin treatment activates an autophagic response that serves as a survival factor to counteract cisplatin-induced cell death, increasing cell drug resistance [19]. To minimize all these routes of resistance, various alternatives have been proposed regarding drug design. On the one side, the use of Pt drugs that attack mitochondrial DNA (mtDNA), rather than nuclear DNA where NER machinery is inactive, represents an attractive alternative to induce cell apoptosis $[20,21]$. The use of (nano-)delivery systems that permit controlled drug release and thus eliminate the problems associated with conventional therapy can also be suggested.

Previously obtained results in our group revealed that ultrasmall iron oxide nanoparticles $(<10 \mathrm{~nm})$ coated with tartaric and adipic acids could be a good vehicle to transport cisplatin (IV) prodrugs. When cells were exposed to these nanoparticles (without the prodrug), they could be easily taken up (up to $4 \mathrm{mM}$ Fe concentration levels) without signs of cell toxicity [21]. In addition, it was observed that their subcellular fate was mainly related to mitochondria, affecting their respiratory and glycolytic parameters, inducing the migration of the cellular state towards quiescence, and promoting and triggering the autophagic process [4]. Therefore, the loading of these nanoparticles with $\mathrm{Pt}(\mathrm{IV})$ - prodrugs was expected to facilitate drug penetration into cells by using endocytic routes and the slow release of the drug locally inside the intracellular targets (nDNA and mtDNA). These effects altogether were expected to induce a more efficient apoptotic pathway when using the $\mathrm{Pt}(\mathrm{IV})$-loaded nanoparticles than when using cisplatin directly.

Therefore, the present work shows the advantages of using ultrasmall iron oxide nanoparticles $(<10 \mathrm{~nm})$ loaded with cisplatin (IV) prodrug compared to using cisplatin. Evaluation of the drug uptake in different cell lines of ovarian cancer, the access to molecular targets (nDNA and mtDNA) and toxicity pathways in terms of cell viability, the level of apoptotic and autophagic cells, and cell cycle arrest are studied.

\section{Materials and Methods}

\subsection{Synthesis of Pt(IV)-Loaded Iron Oxide Nanoparticles}

Iron (III) chloride hexahydrate (98\%, Sigma-Aldrich, Madrid, Spain) was used as a nanoparticle precursor. Sodium tartrate dihydrate (99-101\%, Sigma-Aldrich) and adipic acid (99\%, Sigma-Aldrich) were solubilized in $0.9 \%$ potassium chloride (Merck, Darmstadt, Germany) solution and used as coating agents. Ammonium acetate ( $>98 \%$, SigmaAldrich) was used for the synthesis buffer and $5 \mathrm{~mol} \cdot \mathrm{L}^{-1}$ sodium hydroxide (Merck) was prepared for nanoparticle precipitation. All working standard solutions were prepared using $18 \mathrm{M} \Omega \cdot \mathrm{cm}$ de-ionized water obtained from a PURELAB Flex 3 system (ELGA Veolia, Lane End, UK). Cis-diamminetetrachloroplatinum (IV) (99.9\%) was obtained from Sigma-Aldrich. The synthesis and characterization of the Pt(IV)-loaded nanoparticles (Pt(IV)-FeNPs) followed previously published work [6]. In brief, the iron nanoparticles were first synthesized following previous publications [22] by precipitation of $\mathrm{Fe}^{3+}$ in 
the presence of a highly basic medium $\left(5 \mathrm{~mol} \cdot \mathrm{L}^{-1} \mathrm{NaOH}\right.$ solution) with the addition of tartrate and adipic acid solution. For incorporation of cis-diamminetetrachloroplatinum (IV) (prodrug), a solution of $5 \mathrm{mmol} \cdot \mathrm{L}^{-1}$ of the prodrug was incubated with the particles for $6 \mathrm{~h}$ at room temperature. The excess of the prodrug was eliminated by ultracentrifugation using a 3000 Da Ultra-15 MWCO centrifugal filter. The quantification of the level of loading of the prodrug onto the particles was conducted with HPLC-ICP-MS by monitoring Pt and Fe simultaneously [23]. Each batch of modified nanoparticles was used for 2 weeks and then discarded. During this period, they proved to be stable.

\subsection{Cell Conditions}

The A2780 cell line (ovarian carcinoma) was kindly provided by Dr. J.M. Pérez Freije (Department of Biochemistry and Molecular Biology, University of Oviedo, Spain) and the human ovarian carcinoma cell line OVCAR-3 was purchased from the American Type Culture Collection (ATCC, Manassas, VA, USA). Both lines were authenticated at the Biotechnological and Biomedical Assay Unit of the Scientific and Technical Services (SCTs) at the University of Oviedo. The A2780 cell line was grown in RPMI 1640 medium (Gibco, Waltham, MA, USA) supplemented with 10\% fetal bovine serum (FBS) (Gibco, Waltham, MA, USA) and $5 \mu \mathrm{g} \cdot \mathrm{mL}^{-1}$ Plasmocin Prophylactic (InvivoGen, San Diego, CA, USA). The OVCAR-3 cell line was also grown in RPMI medium but supplemented with $20 \%$ FBS, $0.01 \mathrm{mg} \cdot \mathrm{mL}^{-1}$ of bovine insulin (Sigma Aldrich), and $5 \mu \mathrm{g} \cdot \mathrm{mL}^{-1}$ Plasmocin Prophylactic. All cells were grown at $37^{\circ} \mathrm{C}$ in a $5 \% \mathrm{CO}_{2}$ atmosphere.

\subsection{DNA Isolation}

Isolation of DNA from A2780 was conducted using the PureLink ${ }^{\mathrm{TM}}$ Genomic DNA Mini Kit (Invitrogen, Carlsbad, CA, USA) silica-based column DNA purification kit. The kit was used according to the manufacturer's instructions with the inclusion of RNAse, a treatment to generate RNA-free genomic DNA. The extracted DNA was eluted using $100 \mu \mathrm{L}$ of the elution buffer (10 mM Tris- $\mathrm{HCl}, \mathrm{pH}$ 9.0, $0.1 \mathrm{mM}$ EDTA). The isolation of mtDNA was performed using a Mitochondrial DNA Isolation Kit ${ }^{\mathrm{TM}}$ (Abcam, Cambridge, UK). This kit provides a powerful tool for isolating mtDNA with high yield and purity and without contaminations from genomic DNA, and it was used according the manufacturer's instructions.

DNA purity was confirmed by comparing the ratio of UV measurements at 260 and $280 \mathrm{~nm}$ with the ratio of pure DNA standards. The concentration of isolated DNA was determined by ${ }^{31} \mathrm{P}^{16} \mathrm{O}^{+}$monitoring using ICP-MS after sample digestion using $80 \mu \mathrm{L}$ of $\mathrm{HNO}_{3}(65 \%)$ and $80 \mu \mathrm{L}$ of $\mathrm{H}_{2} \mathrm{O}_{2}(30 \%)$. The sample was further diluted to 1:10 for analysis. $\mathrm{A}^{31} \mathrm{P}^{16} \mathrm{O}^{+}$calibration curve was constructed by applying the same digestion procedure to commercially available calf thymus DNA. Simultaneously, ${ }^{195} \mathrm{Pt}$ was measured within the same experiments. The final results are given as $\mathrm{ng} \mathrm{Pt} / \mathrm{mg}$ DNA.

\subsection{ICP-MS Analysis}

All ICP-MS experiments in this study were performed using the triple quadrupole instrument iCAP TQ ICP-MS (Thermo Fisher Scientific, Bremen, Germany) in single quadrupole (SQ) mode for ${ }^{195} \mathrm{Pt}^{+}$monitoring. For phosphorous measurements, the formation of ${ }^{31} \mathrm{P}^{16} \mathrm{O}^{+}$was achieved by pressurizing the cell with $\mathrm{O}_{2}$. For the chromatography experiments (required for the characterization of the particles) as well as for Pt measurement in DNA, the ICP-MS was fitted with a cyclonic spray chamber and a conventional concentric nebulizer.

\subsection{Cytotoxicity Experiments}

The CellTiter-Blue ${ }^{\mathrm{TM}}$ Cell Viability Assay from Promega (Madison, WI, USA) was carried out in order to assess the cytotoxicity of FeNPs-Pt(IV) in the A2780 cell line. Cells grown in a 96-well flat bottom plate were incubated with FeNPs-Pt(IV) to obtain different concentrations ranging from 0 to $30 \mu \mathrm{M}$ over $24 \mathrm{~h}$ of treatment. Similar experiments were 
conducted by maintaining the cells after exposure for 3 more hours in drug-free RPMI 1640 medium. After the incubation, the nanoparticles and the floating cells were removed and clean medium mixed with CellTiter-Blue ${ }^{\mathrm{TM}}$ Reagent (resazurin dye, $20 \mu \mathrm{L}$ ) was added to each well. The plate was shacked for $10 \mathrm{~s}$ and incubated using standard cell culture conditions for $3 \mathrm{~h}$. The fluorescence was measured at 560/590 nm using the microplate reader. A microplate fluorescence reader, the Varioskan Flash Spectral Scanning Multimode Reader (Thermo Fisher Scientific), was employed for this purpose. Every treatment at every concentration was done in triplicate and the cytotoxicity results are given as the means with the error bars corresponding to the standard deviation. The results for the cytotoxicity induced in A2780 for the nanoparticles without prodrugs are shown in Figure S3.

\subsection{Transmission Electron Microscopy}

After $24 \mathrm{~h}$ exposure to the $\mathrm{Pt}(\mathrm{IV})$-loaded nanoparticles, cells were then fixed with glutaraldehyde and formaldehyde at $4{ }^{\circ} \mathrm{C}$ for $1 \mathrm{~h}$, followed by dehydration with ascending series of alcohol and embedding of the samples in epoxy resin. All these experiments followed the sample preparation protocol used to address the incorporation of titanium dioxide nanoparticles in previous publications [24].

\subsection{Cell Death Mechanism}

\subsubsection{Apoptosis/Necrosis}

Cell apoptosis was measured following the Annexin V-FITC Apoptosis Detection Kit (Sigma Aldrich) protocol. For this purpose, cells grown in a 96-well flat-bottom plate were incubated with the labelled nanoparticles to achieve a final concentration of $20 \mu \mathrm{M}$ of the FeNPs-Pt(IV) over $24 \mathrm{~h}$. Similar experiments were conducted by maintaining the cells after exposure for 3 more hours in drug-free RPMI 1640 medium. Then, $200 \mu \mathrm{L}$ of a binding buffer $\left(5 \times 10^{5}\right.$ cells), $5 \mu \mathrm{L}$ of Annexin V FITC conjugate, and $10 \mu \mathrm{L}$ of propidium iodide (stock of $20 \mu \mathrm{g} \cdot \mathrm{mL}^{-1}$ ) were added to the cells. They were incubated at room temperature in the dark for $10 \mathrm{~min}$ and then they were measured by flow cytometry, counting $1 \times 10^{4}$ events. For these measurements, a CytoFLEX S Flow Cytometer (Beckman Coulter, Brea, CA, USA) was used. The results for the cell necrosis and apoptosis induced in A2780 for the nanoparticles without prodrugs are shown in Figure S4.

\subsubsection{Autophagy Induction}

Autophagy in A2780 cells was evaluated by flow cytometry using the CYTO-ID ENZKIT175 Autophagy Detection Kit 2.0 (Enzo Life Sciences, Lausen, Switzerland) following the manufacturer's instructions. In brief, $1 \times 10^{5}$ cells $/ \mathrm{mL}$ were seeded in 6 -well plates and incubated with the conditions described above for $24 \mathrm{~h}$ with $20 \mu \mathrm{M}$ of FeNPs-Pt(IV). Similar experiments were conducted by maintaining the cells after exposure for 3 more hours in drug-free RPMI 1640 medium. A total of $500 \mathrm{nM}$ of rapamycin was used as the positive control. Trypsin was used to detach cells from the wells, and Assay Buffer $1 \times$ was used for washing. Cells were incubated in RPMI 1640 medium without phenol red indicator and with green stain solution for $30 \mathrm{~min}$ at room temperature. Cells were collected, washed with Assay Buffer $1 \times$, and suspended in Assay Buffer $1 \times$ before being analyzed in a flow cytometer (Becton Dickinson Biosciences, East Rutherford, NJ, USA). The software FACS Diva 6.1 (Becton Dickinson Biosciences) was used to analyze the results of the experiments. Furthermore, p62 levels were studied using an ELISA kit (Enzo Life Sciences, Lausen, Switzerland), according to the instructions provided by the manufacturer. The experiment was performed in triplicate.

\subsection{Cell Cycle Arrest Study}

The cell cycle was measured following the Invitrogen protocol. Briefly, cell suspensions $\left(5 \times 10^{5}\right.$ cells previously exposed to $20 \mu \mathrm{M}$ of FeNPs-Pt(IV) for $24 \mathrm{~h}$ or $24 \mathrm{~h}$ plus a recovery time in drug-free media for 3 more hours) were fixed with $\mathrm{EtOH} 70 \%$, washed with PBS, and $100 \mu \mathrm{L}$ of PBS was added. A solution of RNAse $\left(120 \mu \mathrm{L}\right.$ of $\left.100 \mu \mathrm{g} \cdot \mathrm{mL}^{-1}\right)$ and propidium 
iodide $\left(120 \mu \mathrm{L}\right.$ of $\left.140 \mu \mathrm{g} \cdot \mathrm{mL}^{-1}\right)$ was added and the solution was incubated for $30 \mathrm{~min}$. Cells were measured by cytometry counting $1 \times 10^{4}$ events and the data were analyzed with Modfit Lt (Verity Software House, ME, USA) software. The results for the cell necrosis and apoptosis induced in A2780 for the nanoparticles without prodrugs are shown in Figure S5.

\subsection{Statistical Analysis}

Statistical analysis was performed using Student's t-test and a $p$-value of $<0.05$ was considered as significant. In addition, the F-test was performed to compare variances among datasets. In the cases when $\mathrm{F}_{\text {experimental }}<\mathrm{F}_{\text {critical }}\left(\mathrm{F}_{\text {exp }}<\mathrm{F}_{\text {cri }}\right)$ and, thus, no significant differences among SDs were detected, Student's t-test was applied. When $\mathrm{F}_{\text {exp }}>\mathrm{F}_{\text {cri }}$, instead of Student's $t$-test, the Welch test was applied.

\section{Results and Discussion}

\subsection{Quantitative Platination Studies of Nuclear and Mitochondrial DNA}

The use of nanoparticles in medicine could lead to the development of new treatment strategies and tools for therapy. Thus, previous work has demonstrated that iron nanoparticles have the capacity to be efficient carriers of moieties such as drugs or genes due to their biocompatibility, easy synthesis, and reduced size [25]. In this study, the conjugation of cisplatin (IV) prodrugs to ultrasmall FeNPs was expected to provide very efficient incorporation of the drug into the cell cytosol through endocytic routes. Thus, A2780 cells were treated with $20 \mu \mathrm{M}$ Pt (in the form of Pt(IV)-FeNPs), and the TEM results are plotted in Figure 1. It was possible to observe the presence of the Pt(IV)-FeNPs within the cells either individually or in small aggregates (yellow circles; elemental analysis is provided in the Supplementary Materials, Figure S1), which might have been due to the formation of an early endosome through a mechanism involving an endosomal pathway, as previously described $[4,26]$. Such mechanisms can be used to improve drug internalization and help to circumvent the intracellular pathways and biological barriers of the free drugs.
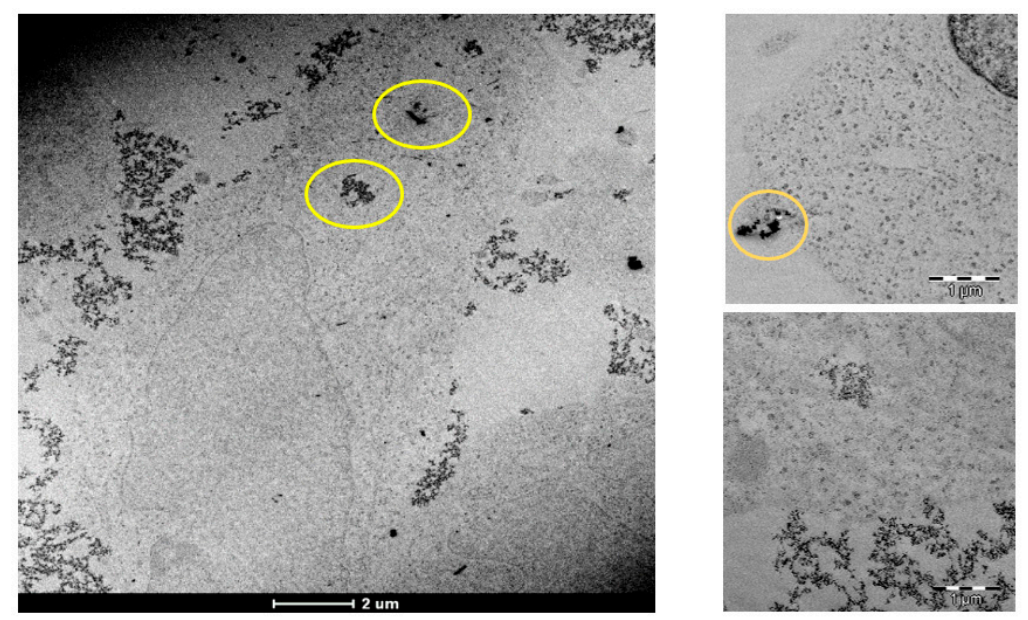

Figure 1. Transmission electron microscopy (TEM) of cells after exposure to $20 \mu \mathrm{M}$ Pt as Pt(IV)-loaded iron oxide nanoparticles for $24 \mathrm{~h}$ (nanoparticles marked with yellow circles).

To further evaluate the enhanced transport of the $\mathrm{Pt}(\mathrm{IV})$ prodrug loaded onto the nanoparticles, quantitative Pt incorporation results were calculated using ICP-MS. The results obtained for A2780 cell line revealed average concentrations of about $12.3 \pm 2.1 \mathrm{fg}$ $\mathrm{Pt} /$ cell versus $3.17 \pm 0.76 \mathrm{fg} \mathrm{Pt} /$ cell when using cisplatin directly (see the Supplementary Materials, Figure S2). Considering a Pt concentration of $20 \mu \mathrm{M}$ in both cases, the levels taken up corresponded to $0.15 \%$ and $0.05 \%$, respectively, of the Pt given to the cells. Thus, the use of $\mathrm{Pt}(\mathrm{IV})$-loaded nanoparticles increased the drug incorporation levels by a factor of three to four. Such differences were not as dramatic in other tested ovarian cancer cells (e.g., OVCAR-3) exposed to $20 \mu \mathrm{M}$ (see the Supplementary Materials, Figure S2), 
which showed significantly lower sensitivity to cisplatin ( $\mathrm{IC}_{50} 30 \mu \mathrm{M}$ for cisplatin in this cell model). In the case of the A2780, the enhanced transport efficiency provided by the nanoparticles with respect to free cisplatin would have reduced the drug concentration required to obtain comparable cellular toxicity. In addition, the activation of the pre-target resistance mechanisms (like the increased detoxification and efflux of the drug) might have been decreased due to the slow release of the drug from the nanoparticle surface $[27,28]$.

Once in the cytosol, the pathway taken by the $\mathrm{Pt}(\mathrm{IV})$ prodrug to reach nuclear DNA requires its reduction to $\mathrm{Pt}(\mathrm{II})$ in the presence of reducing molecules like ascorbic acid or glutathione, with the consequent loss of the axial ligands [14]. This process should produce functional cisplatin (II) that can reach the cell nucleus or the mitochondria to interact with DNA, forming the so-called DNA-cisplatin adducts. Firstly, the isolation of nuclear DNA was conducted, and the platination results can be observed in Figure 2. As can be seen, immediately after exposure $(t=0 \mathrm{~h})$, cells showed about $250 \pm 50 \mathrm{ng} \mathrm{Pt} / \mathrm{mg}$ DNA. Taking into account the intracellular Pt $(12.3 \pm 2.1 \mathrm{fg} \mathrm{Pt} /$ cell $)$ and the estimated amount of DNA per cell (about 6 pg DNA/cell), the maximum expected concentration of the drug associated with DNA would be $2500 \mathrm{ng} \mathrm{Pt} / \mathrm{mg}$ DNA. Thus, the observed $250 \pm 50 \mathrm{ng} \mathrm{Pt} / \mathrm{mg}$ DNA represented about $10 \%$ of the cytosolic Pt bound to DNA. This concentration increased significantly (by about fivefold) when the cells were left to stand for $3 \mathrm{~h}$ in drug-free media $(\mathrm{t}=3 \mathrm{~h})$, reaching levels of approximately $1300 \mathrm{ng} \mathrm{Pt} / \mathrm{mg}$ DNA, which represented about $60 \%$ of the Pt taken up. These results can be explained by the time-dependent release of cisplatin from the Pt(IV)-FeNPs in the cell cytosol, as previously observed in model solutions [23]. In the case of the OVCAR-3 cell line, despite the fact that the cell uptake was significantly lower, the DNA-bound Pt concentration $(28 \mathrm{ng} \mathrm{Pt} / \mathrm{mg}$ DNA) after $24 \mathrm{~h}$ exposure also corresponded to approximately $10 \%$ of the concentration taken up (1.6 fg/cell).

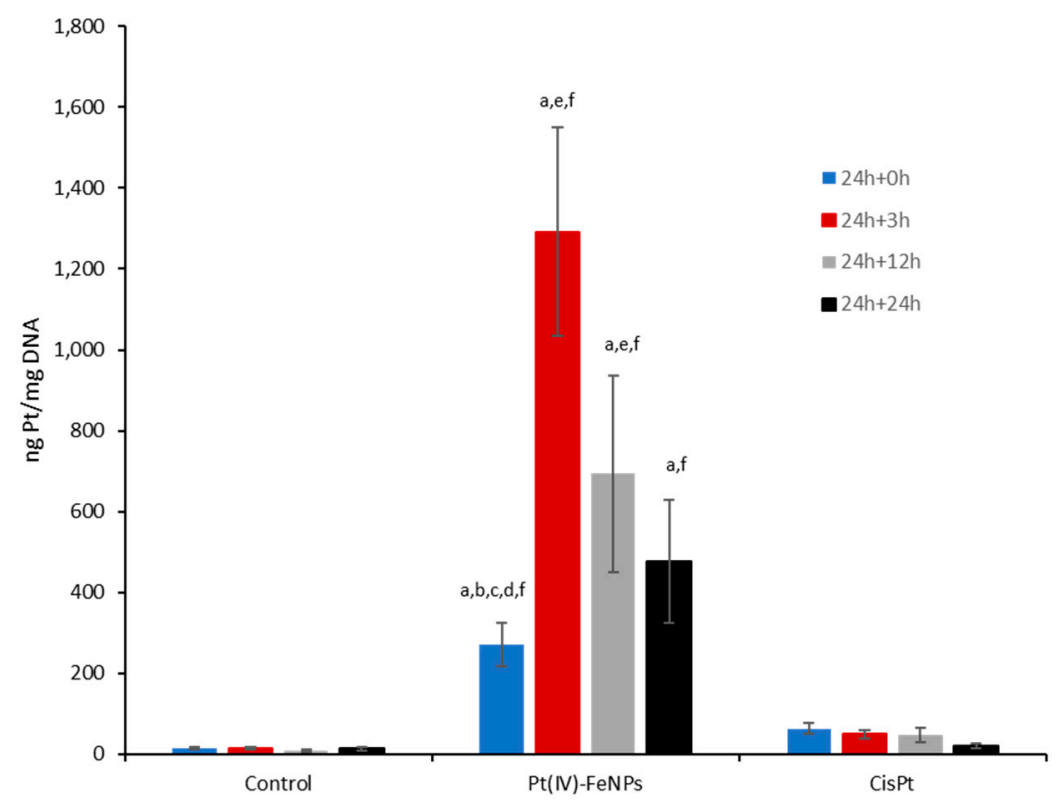

Figure 2. Accumulation of Pt in DNA after exposure to $20 \mu \mathrm{M} \mathrm{Pt}$ as $\mathrm{Pt}(\mathrm{IV})$-loaded iron oxide nanoparticles for $24 \mathrm{~h} ; \mathrm{t}=0 \mathrm{~h}$ corresponds to the measurement right after exposure, $\mathrm{t}=3 \mathrm{~h}$ corresponds to the measurement after $3 \mathrm{~h}$ cell rest in drug-free media, $\mathrm{t}=12 \mathrm{~h}$ and $\mathrm{t}=24 \mathrm{~h}$ correspond to cell rest for $12 \mathrm{~h}$ and $24 \mathrm{~h}$ respectively. The same experiments were undertaken with cisplatin. $p<0.05$ (a) against control; (b) against Pt(IV)-FeNPs $24 \mathrm{~h}$ treatment, $\mathrm{t}=0 \mathrm{~h}$; (c) against Pt(IV)-FeNPs, $\mathrm{t}=3 \mathrm{~h}$; (d) against $\mathrm{Pt}(\mathrm{IV})-\mathrm{FeNPs}, \mathrm{t}=12 \mathrm{~h}$; (e) against $\mathrm{Pt}(\mathrm{IV})-\mathrm{FeNPs}, \mathrm{t}=24 \mathrm{~h}$; (f) against cisplatin $24 \mathrm{~h}$ treatment.

When the cells were left to stand for $12 \mathrm{~h}$ and $24 \mathrm{~h}$ respectively in drug-free media $(t=12 \mathrm{~h}$ and $\mathrm{t}=24 \mathrm{~h})$, the Pt-DNA adducts could be repaired thanks to some of the existing mechanisms for cells survival (e.g., NER), thus reducing the Pt detected in DNA. 
The treatment with cisplatin at the same concentration, on the other hand (see Figure 2), resulted in the highest Pt concentration in DNA (50 ng Pt/ mg DNA) at the end of the exposure period. This corresponded to $10 \%$ of the cisplatin incorporated in the cytosol (a similar percentage to what was found when using the Pt(IV)-FeNPs), followed by a decrease after $3(4 \%), 12(7 \%)$ and $24 \mathrm{~h}(3 \%)$, possibly due to the repair of the formed adducts.

Similar measurements were taken for mtDNA (after isolation with the specific kit as detailed in the Materials and Methods section) and the results can be seen in Figure 3. As in the case of nDNA, the Pt concentration in mtDNA was significantly higher when using the $\mathrm{Pt}(\mathrm{IV})$-FeNPs $(8400 \pm 55 \mathrm{ng} \mathrm{Pt} / \mathrm{mg} \mathrm{DNA})$ than when using cisplatin directly $(108 \pm 8 \mathrm{ng} \mathrm{Pt} / \mathrm{mg}$ DNA).

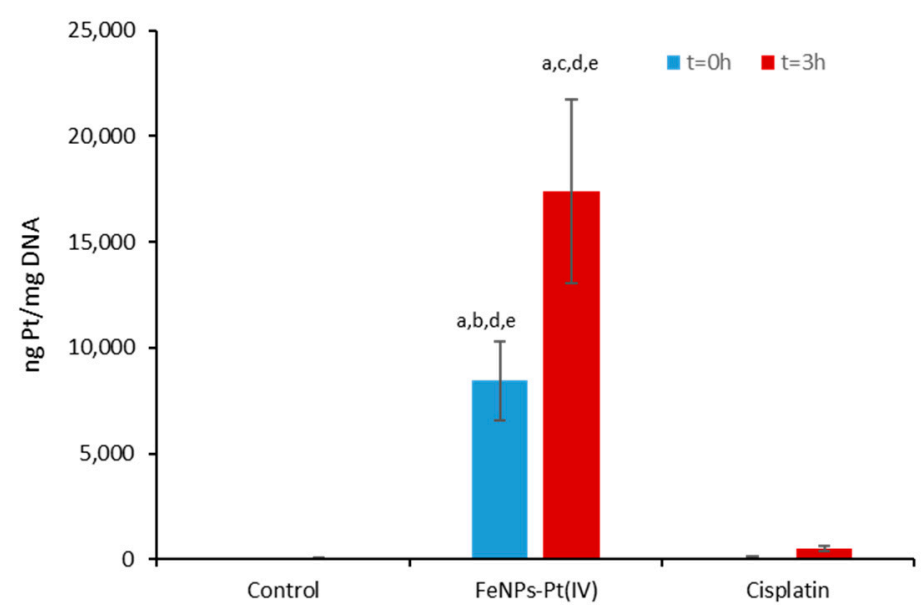

Figure 3. Accumulation of $\mathrm{Pt}$ in mitochondrial DNA after exposure to $20 \mu \mathrm{M}$ of $\mathrm{Pt}(\mathrm{IV})$-loaded iron nanoparticles for $24 \mathrm{~h}(\mathrm{t}=0 \mathrm{~h})$ and after leaving cells in drug-free media for $3 \mathrm{~h}(\mathrm{t}=3 \mathrm{~h})$. The same experiments were performed with cisplatin. $p<0.05$ (a) against control; (b) against Pt(IV)-FeNPs $(\mathrm{t}=0 \mathrm{~h}) ;(\mathbf{c})$ against Pt(IV)-FeNPs $(\mathrm{t}=3 \mathrm{~h}) ;(\mathbf{d})$ against cisplatin $(\mathrm{t}=0 \mathrm{~h}) ;(\mathbf{e})$ against cisplatin $(\mathrm{t}=3 \mathrm{~h})$.

As previously stated, initial experiments conducted with these nanoparticles revealed that their subcellular fate was related to mitochondria [4]; thus, the high concentration of $\mathrm{Pt}$ in this organelle was in some sense expected. Furthermore, after $\mathrm{t}=3 \mathrm{~h}$ in drug-free media, the concentration was twofold higher (up to $17,400 \pm 75 \mathrm{ng} \mathrm{Pt} / \mathrm{mg}$ DNA), showing that the platination of mtDNA when using Pt(IV)-FeNPs was also more efficient here than when using cisplatin directly and required, as in the case of nDNA, a time lapse. Therefore, once cisplatin was released from the nanoparticles, the quantity of adducts formed with mtDNA increased by as much as 30-fold compared to nDNA, and this must be considered a significant contribution to cell toxicity, as proposed by other authors [19,29].

\subsection{Cellular Viability, Apoptosis, and Cell Cycle Arrest}

A cellular viability test was conducted to evaluate the effect of the Pt(IV)-loaded nanoparticles at different concentrations in the A2780 cell model immediately after $24 \mathrm{~h}$ of exposure $(t=0)$ and after different durations of cell rest in drug-free media. These results are collected in Figure 4. 


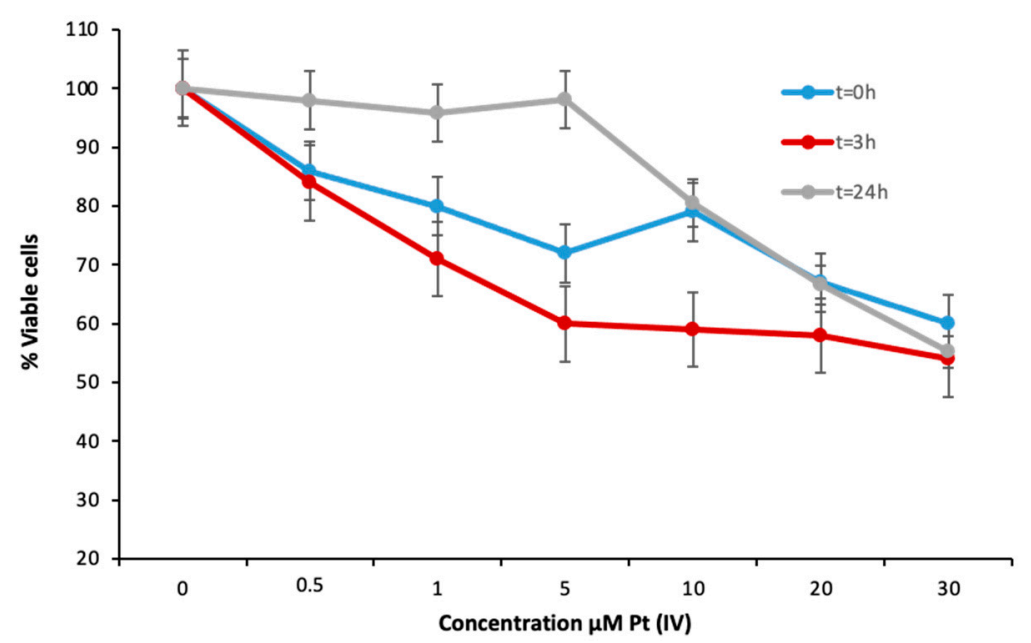

Figure 4. Cell viability results evaluated for A2780 cells treated with $\mathrm{Pt}(\mathrm{IV})$-loaded iron oxide nanoparticles at concentrations ranging from 0 to $30 \mu \mathrm{M}$ for $24 \mathrm{~h}(\mathrm{t}=0 \mathrm{~h})$ and after cell rest in drug-free media for $3 \mathrm{~h}(\mathrm{t}=3 \mathrm{~h})$ and $24 \mathrm{~h}(\mathrm{t}=24 \mathrm{~h})$.

As can be seen, there were two different trends in the obtained data for the exposure concentrations: from 0 to $5 \mu \mathrm{M}$, a progressive decrease in cell viability occurred for cells measured at $\mathrm{t}=0$ (blue dots) and, similarly, after $\mathrm{t}=3 \mathrm{~h}$ in drug-free media (red dots). However, the cell viability remained almost constant (about 100\%) when cells were measured after $24 \mathrm{~h}$ in drug-free media ( $\mathrm{t}=24 \mathrm{~h}$, grey dots) in this range of concentrations. By comparing these results with the DNA platination results, it is possible to associate the decrease in cell viability at $t=0$ and $t=3 \mathrm{~h}$ with the increase of DNA platination (see Figure 2). Apparently, after $3 \mathrm{~h}$ in drug-free media, the Pt species were still being released from the nanoparticle surface due to the cytosolic reducing agents, forming the so-called DNA adducts and inducing a decrease in cell viability. However, when cells were left to stand for $24 \mathrm{~h}$ in drug-free media (grey dots), the DNA repairing mechanism started to act, counteracting the formation of the adducts with their elimination (see Figure 2). Thus, only higher concentrations of the Pt(IV)-loaded nanoparticles $(>5 \mathrm{mM})$ demonstrated a significant decrease in cell viability. Taken together, these results reveal the importance of the kinetics of the different processes occurring inside the cell in relation to the $\mathrm{Pt}(\mathrm{IV})$-loaded nanoparticles for the elucidation of the toxicity mechanisms.

To further elucidate whether the platination of DNA (both nDNA and mtDNA) resulted in in the activation of the apoptotic pathway, as occurs when cells are treated with cisplatin [30], cells were tested for apoptosis/necrosis. For this purpose, cells were stained with propidium iodate and Annexin V. Annexin V specifically binds phosphatidylserine in the cell membrane in which the cells entered into the apoptotic phase, whereas PI stains DNA in necrotic cells where the cell membrane disintegrates. The results of cell exposure to $20 \mu \mathrm{M}$ of the $\mathrm{Pt}(\mathrm{IV})$-loaded nanoparticles at $\mathrm{t}=0$ and $\mathrm{t}=3 \mathrm{~h}$ in drug-free media can be seen in Figure 5A,B, respectively. As can be observed, Pt(IV)-loaded particles induced apoptosis/necrosis in A2780 cells in a time-dependent manner. At $t=0 \mathrm{~h}$, cell damage was induced, accounting for approximately $14 \%$ apoptosis and about $5.5 \%$ necrosis compared to the control cells. At $\mathrm{t}=3 \mathrm{~h}$, the percentage of apoptotic cells increased significantly up to about $22 \%$, while necrotic cells remained constant or even decreased slightly. These results were in agreement with the cell viability tests and also with the DNA platination results, confirming that when using the Pt(IV)-loaded nanoparticles, the main mechanism of cell toxicity seemed to be the apoptotic route, as in the case of cisplatin. 
(A)
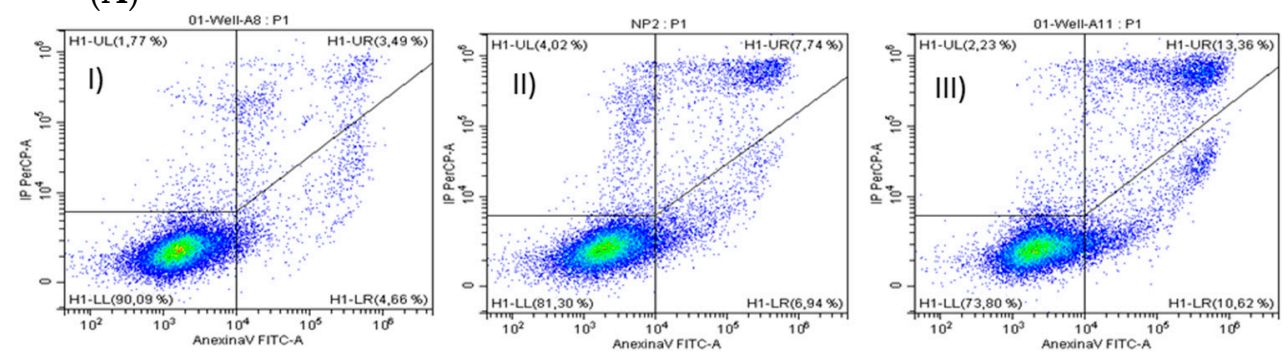

(B)

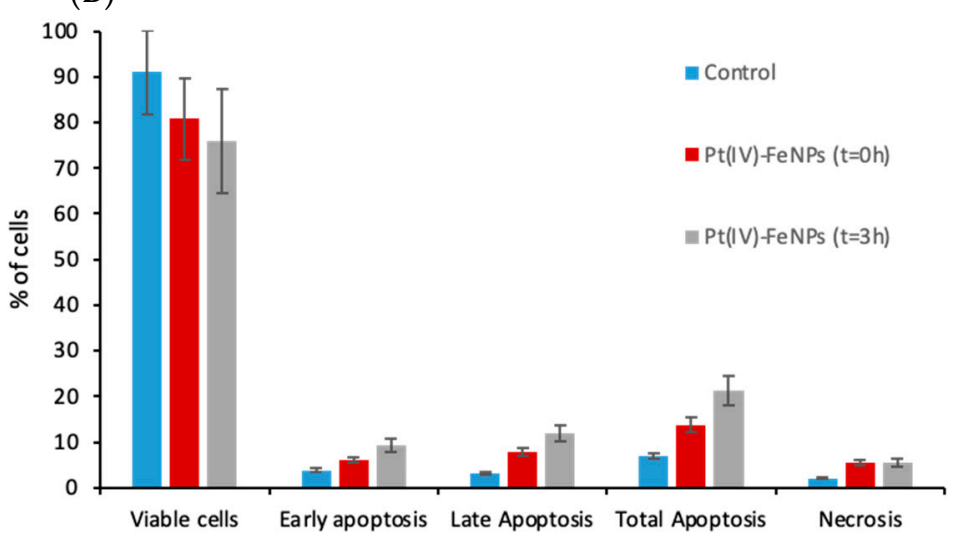

Figure 5. (A) Viable, apoptotic, and necrotic cell flow cytometry results for (I) control and (II) cells exposed to $20 \mu \mathrm{M}$ of iron nanoparticles covered by cisplatin (IV) prodrug for $24 \mathrm{~h}$ and (III) $\mathrm{t}=3 \mathrm{~h}$ in drug-free media. (B) Graphic representation of cell percentages at each cell stage. For viable cells and total apoptosis, the results were statistically different against control at $\mathrm{t}=0$ and $\mathrm{t}=3 \mathrm{~h}$ for $p<0.05$.

The formation of Pt-DNA adducts was found to block DNA replication, which could subsequently cause inhibition of cell proliferation. Therefore, to complete the study on the $\mathrm{Pt}(\mathrm{IV})$ loaded nanoparticles, it was necessary to address the question of whether they exerted the same effect on the cell cycle. Cell cycle analysis through quantitation of DNA content takes into account the fact that cells that are in the $S$ phase have more DNA than cells in G1; therefore, they take up proportionally more dye and fluoresce more brightly. The cells in G2 are approximately twice as bright as cells in G1. Figure 6 shows the results corresponding to the cell cycle arrest in control cells, at $t=0$, and at $t=3 \mathrm{~h}$ of cell rest in drug-free media. As can be seen, upon exposure $(t=0)$, among the cell cycle phases, the $S$ phase was the most severely affected by the treatment with the $\mathrm{Pt}(\mathrm{IV})$-loaded nanoparticles that occurred at the earliest times. More cells were arrested in the $S$ phase $(30 \%)$ compared to the control $(10 \%)$.

These results are consistent with those from previous publications [31] that also demonstrated that slowed progression through the $\mathrm{S}$ phase was the most important cytokinetic event in the case of cisplatin treatment. In addition, the same authors showed that the cell cycle perturbations correlated with the level of DNA damage, mainly in the form of DNA adducts. This was also observed in this case when using Pt(IV)-loaded nanoparticles. However, the cell cycle arrest in the $\mathrm{S}$ phase after $\mathrm{t}=3 \mathrm{~h}$ in drug-free media, although statistically significant, did not show a dramatic increase compared to that observed at $\mathrm{t}=0$ ( $34 \%$ versus $30 \%$ ). Since the S phase corresponds to the phase in which DNA is synthesized, the number of adducts formed at $t=0$ seems to have been high enough to prevent DNA replication, thus inducing cell cycle arrest in this phase and inhibiting the progression to G2 even more. 


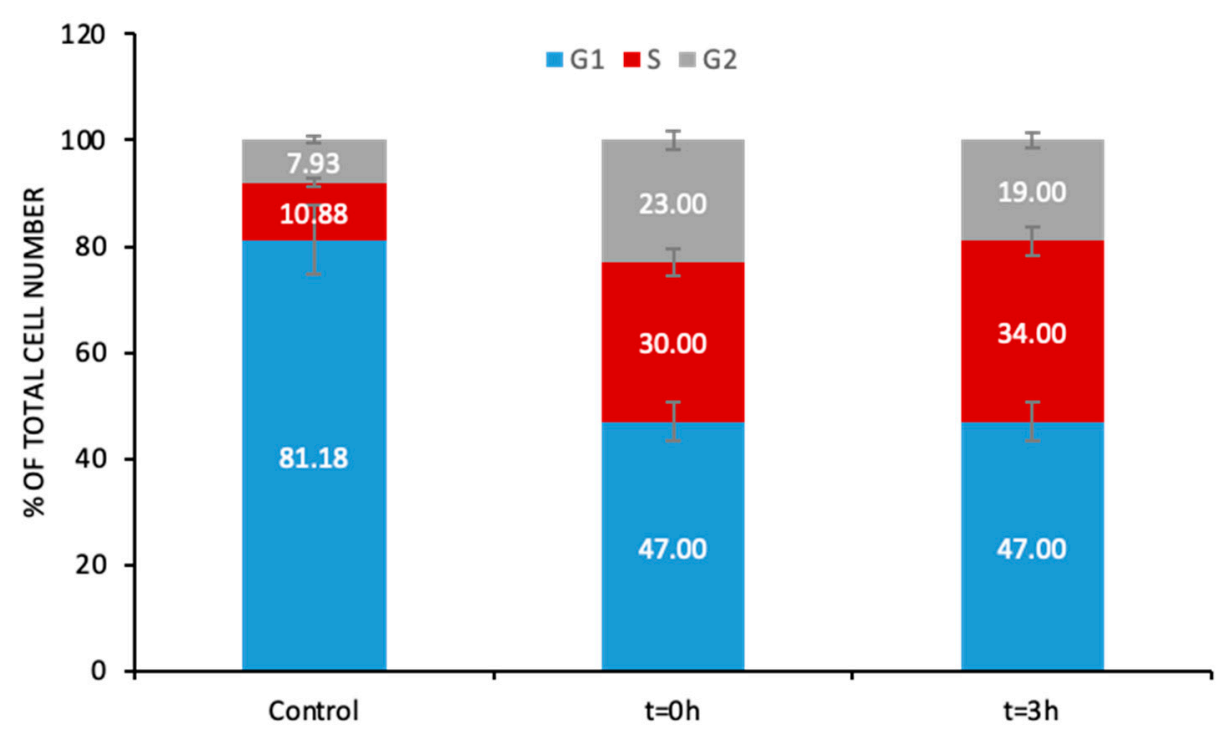

Figure 6. Cell cycle percentages for each cycle stage for cells treated with $20 \mu \mathrm{M} \mathrm{Pt}$ as $\mathrm{Pt}(\mathrm{IV})$-loaded iron oxide nanoparticles for $24 \mathrm{~h}(\mathrm{t}=0 \mathrm{~h})$ and after cell rest in drug-free media $(\mathrm{t}=3 \mathrm{~h})$. For G1, $\mathrm{S}$, and G2, the results were statistically different against control for $p<0.05$.

\subsection{Autophagy}

Autophagy is a highly conserved process by which cytoplasmic components are sequestered in double membrane vesicles called autophagosomes and degraded upon fusion with lysosomal compartments. In fact, recent studies have indicated that acute cisplatin treatment activates an autophagic response that serves as a survival factor to counteract cisplatin-induced cell death. In this case, the Pt(IV)-loaded nanoparticles must be studied as potential inductors of autophagy as a cell defense mechanism or, on the contrary, as "Trojan horses" introducing Pt intracellularly more efficiently than the administration of cisplatin. For this purpose, cells exposed to $20 \mu \mathrm{M}$ of Pt(IV)-loaded nanoparticles at $t=0$ and at $t=3 \mathrm{~h}$ after cell rest in drug-free media were measured for the production of autophagosomes. To achieve this, fluorescence signaling was performed using two dyes: Hoechst 33342 dye and Cyto-ID ${ }^{\circledR}$ Green dye. As can be observed in Figure 7A, the treatment of A2780 cells with the $\mathrm{Pt}(\mathrm{IV})$-loaded nanoparticles led to a higher content of autophagic vacuoles compared to the control group ( $6 \%$ versus $1 \%)$, but it was significantly lower than that found in cells treated with the inductor of autophagy (rapamycin). Moreover, after $\mathrm{t}=3 \mathrm{~h}$ in drug-free media, the number of autophagic cells decreased from $6 \%$ to $3 \%$.

In addition, to determine whether the autophagic flux was initiated by the Pt(IV)FeNPs, p62 was determined (see Figure 7B). As can be seen in the figure, p62 decreased when cells were treated with $\mathrm{Pt}(\mathrm{IV})-\mathrm{FeNPs}$, producing a similar effect as rapamycin (positive control). Similar to the formation of autophagic vacuoles, when cells were left in drug-free media $(t=3 \mathrm{~h})$ this effect reversed to the level of the control sample. Taken together, these results can be explained as an initial cellular response to eliminate the endocyted particles (at $t=0 \mathrm{~h}$ ). Afterwards, the activation of the apoptosis routes (at $t=3 \mathrm{~h}$ ) to induce irreversible cell damage could not be counteracted by the formation of the autophagic vacuoles and, therefore, the initial values decreased and the levels of p62 were reestablished.

By comparing these results with those previously observed when evaluating the "naked" nanoparticles (without loading them with the prodrug) [4], it can be concluded that the induction of autophagy can be ascribed to the presence of the nanoparticles and not to the loading with the prodrug. Thus, these data confirmed that the autophagic process can be modulated by ultrasmall iron nanoparticles themselves, providing an excellent and efficient platform for the development of a new drug delivery nanosystem to overcome autophagy-mediated cisplatin resistance. 


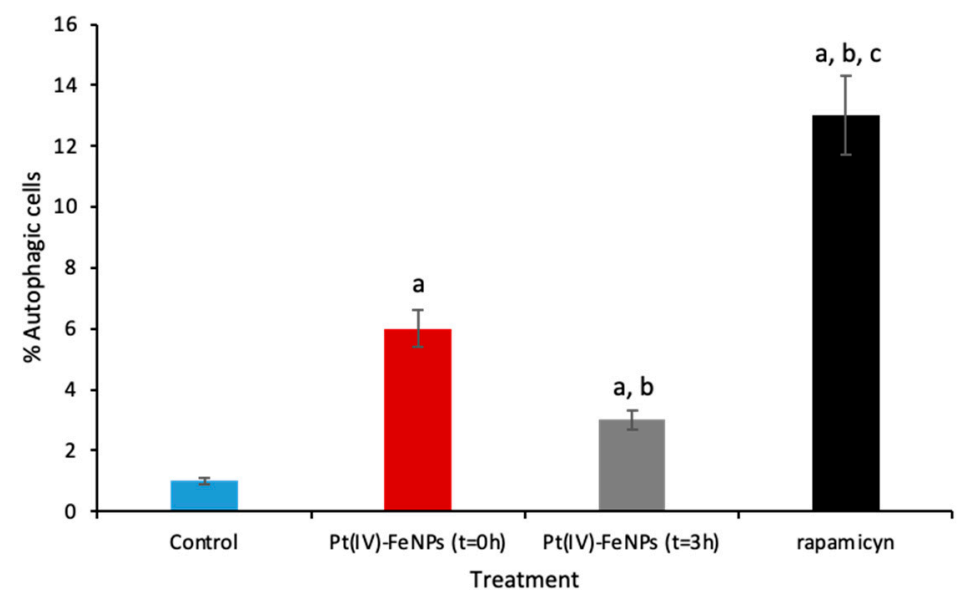

(A)

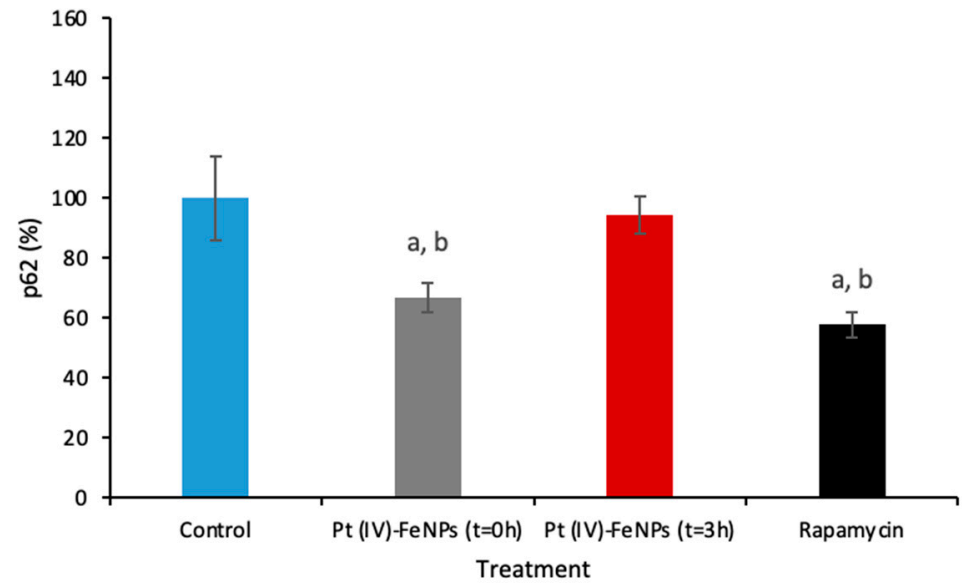

(B)

Figure 7. (A) Induction of autophagy evaluated by flow cytometry for cells treated with $20 \mu \mathrm{M} \mathrm{Pt}$ as $\mathrm{Pt}(\mathrm{IV})$-loaded iron oxide nanoparticles for $24 \mathrm{~h}(\mathrm{t}=0 \mathrm{~h})$ and after cell rest in drug-free media $(\mathrm{t}=3$ h): (a) vs. control; (b) vs. Pt(IV)-FeNPs $(\mathrm{t}=0 \mathrm{~h})$; (c) vs. Pt(IV)-FeNPs $(\mathrm{t}=3 \mathrm{~h})$. (B) Percentage of p62 (compared to control cells) in A2780 cells treated with $20 \mu \mathrm{M} \mathrm{Pt}$ as Pt(IV)-loaded iron oxide nanoparticles for $24 \mathrm{~h}(\mathrm{t}=0 \mathrm{~h})$ and after cell rest in drug-free media $(\mathrm{t}=3 \mathrm{~h})$ : (a) vs. control; (b) vs. $\mathrm{Pt}(\mathrm{IV})-\mathrm{FeNPs}(\mathrm{t}=3 \mathrm{~h})$.

\section{Conclusions}

The viability of using ultrasmall iron oxide nanoparticles to enhance intracellular delivery of a $\mathrm{Pt}(\mathrm{IV})$ prodrug was proved by observing the presence of the nanoparticles in the cell cytosol using TEM and, quantitatively, by measuring Pt using ICP-MS. The incorporated prodrug undergoes further intracellular reduction to form functional cisplatin (II) and its interaction with DNA (nuclear and mitochondrial) is superior to that of cisplatin. This mechanism, however, was found to be time-dependent, achieving maximum platination levels for both nDNA and mtDNA after the cells were left in drug-free media for $3 \mathrm{~h}$ following the exposure period. The level of the formation of adducts could be correlated with the decrease in the cell viability, even at lower concentrations, at $t=0 \mathrm{~h}$ and $\mathrm{t}=3 \mathrm{~h}$ after exposure. Longer times in drug-free media $(t=24 \mathrm{~h})$ started to show the effect of the cellular repair mechanisms (e.g., NER), yielding higher cell viability. The main mechanism of cell damage, once the adducts were formed, was apoptosis. In addition, cell arrest in the $S$ phase confirmed that there was analogous behavior to that of cisplatin. In summary, the use of a nanodelivery system like ultrasmall iron oxide nanoparticles can serve to enhance 
prodrug penetration in cells, allowing the reduction of the employed doses, which are often the cause of systemic toxicity. The prodrug undergoes time-dependent intracellular reduction to cisplatin (II), and this phenomenon occurs more efficiently in the reducing environment of tumor cells. The main advantage is the "in situ" production of the intracellularly active cisplatin (II), which is able to induce cell death. Collectively, these results suggest that ultrasmall iron oxide nanoparticles, due to their small diameter, can be used to deliver cisplatin into cancer cells in a sustained manner in the long term, avoiding multiple administrations.

Supplementary Materials: The following are available online at https:/ /www.mdpi.com/article/ 10.3390/pharmaceutics13101730/s1, Figure S1: (A) EDX analysis of the nanoparticles observed by (B) TEM present within the cell cytosol (arrows pointing the Pt and Fe signals). Since Pt is only present on the surface of the particles, the intensity is significantly smaller; Figure S2: Incorporation results of Pt in the A2780 and OVCAR-3 exposed to cisplatin and to the Pt(IV) loaded nanoparticles; Figure S3: Viability results obtained for the naked particles at different concentrations after $24 \mathrm{~h}$ exposure; Figure S4: Apoptosis evaluated for the naked particles after $24 \mathrm{~h}$ and $24+3 \mathrm{~h}$ of cell rest; Figure S5: Cell cycle experiments for the naked particles after $24 \mathrm{~h}$ and $24+3 \mathrm{~h}$ of cell rest.

Author Contributions: L.G.-R.: Formal analysis, Investigation, Writing—Review \& Editing; L.R.-G.: Conceptualization, Methodology, Writing-Review \& Editing; C.S.-G.: Methodology, WritingReview \& Editing, Supervision; J.L.: Methodology, Writing—Review \& Editing; E.B.: Conceptualization, Funding acquisition; M.M.-B.: Conceptualization, Methodology, Formal analysis, WritingReview \& Editing, Funding acquisition. All authors have read and agreed to the published version of the manuscript.

Funding: The financial support through the regional funding from the government of Asturias through the Science, Technology and Innovation Plan (PCTI), co-financed by FEDER funds (ref. FCGRUPIN-IDI/2018/000242), and the funding from the Spanish Ministry of Economy, Industry and Competitiveness (MINECO) through the project RTI2018-094605-B-I00 are gratefully acknowledged. Thermo Fisher Scientific (Bremen, Germany) is kindly acknowledged for the instrumental support.

Institutional Review Board Statement: Not applicable.

Data Availability Statement: Not applicable.

Acknowledgments: The authors kindly acknowledge Marcos García-Ocaña and Ana Cristina Salas Bustamante from the Biotechnology and Biomedical Analysis Unit of the University of Oviedo for the cell culture and advice.

Conflicts of Interest: The authors declare no conflict of interest.

\section{References}

1. Cohen, S.M.; Lippard, S.J. Cisplatin: From DNA damage to cancer chemotherapy. Prog. Nucleic Acid Res. Mol. Biol. 2001, 67, 93-100. [CrossRef]

2. Wang, D.; Lippard, S.J. Cellular processing of platinum anticancer drugs. Nat. Rev. Drug Discov. 2005, 4, 307-320. [CrossRef]

3. Galluzzi, L.; Vitale, I.; Michels, J.; Brenner, C.; Szabadkai, G.; Harel-Bellan, A.; Castedo, M.; Kroemer, G. Systems biology of cisplatin resistance: Past, present and future. Cell Death Dis. 2014, 5, e1257. [CrossRef]

4. Rivas-García, L.; Quiles, J.L.; Varela-López, A.; Giampieri, F.; Battino, M.; Bettmer, J.; Montes-Bayón, M.; Llopis, J.; SánchezGonzález, C. Ultra-small iron nanoparticles target mitochondria inducing autophagy, acting on mitochondrial dna and reducing respiration. Pharmaceutics 2021, 13, 90. [CrossRef]

5. Rottemberg, S.; Disler, C.; Perego, P. The rediscovery of platinum-based cancer therapy. Nat. Rev. Cancer 2021, 21, 37-50. [CrossRef]

6. Ishida, S.; Lee, J.; Thiele, D.J.; Herskowitz, I. Uptake of the anticancer drug cisplatin mediated by the copper transporter Ctr1 in yeast and mammals. Proc. Natl. Acad. Sci. USA 2002, 99, 14298-14302. [CrossRef]

7. Koushik, O.; Rao, Y.; Kumar, P.; Karthikeyan, R. Nano Drug Delivery Systems to Overcome Cancer Drug Resistance-A Review. J. Nanomed. Nanotechnol. 2016, 7, 2. [CrossRef]

8. Kim, J.; Piao, Y.; Hyeon, T. Multifunctional nanostructured materials for multimodal imaging, and simultaneous imaging and therapy. Chem. Soc. Rev. 2009, 38, 372-390. [CrossRef]

9. Wang, J.; Sui, M.; Fan, W. Nanoparticles for Tumor Targeted Therapies and Their Pharmacokinetics. Curr. Drug Metab. 2010, 11, 129-141. [CrossRef] 
10. Johnstone, T.C.; Suntharalingam, K.; Lippard, S.J. The Next Generation of Platinum Drugs: Targeted Pt(II) Agents, Nanoparticle Delivery, and Pt(IV) Prodrugs. Chem. Rev. 2016, 116, 3436-3486. [CrossRef]

11. Dhar, S.; Daniel, W.L.; Giljohann, D.A.; Mirkin, C.A.; Lippard, S.J. Polyvalent oligonucleotide gold nanoparticle conjugates as delivery vehicles for platinum(IV) warheads. J. Am. Chem. Soc. 2009, 131, 14652-14653. [CrossRef]

12. Ma, P.; Xiao, H.; Yu, C.; Liu, J.; Cheng, Z.; Song, H.; Zhang, X.; Li, C.; Wang, J.; Gu, Z.; et al. Enhanced Cisplatin Chemotherapy by Iron Oxide Nanocarrier-Mediated Generation of Highly Toxic Reactive Oxygen Species. Nano Lett. 2017, 17, 928-937. [CrossRef] [PubMed]

13. Zhang, S.; Zhong, X.; Yuan, H.; Guo, Y.; Song, D.; Qi, F.; Zhu, Z.; Wang, X.; Guo, Z. Interfering in apoptosis and DNA repair of cancer cells to conquer cisplatin resistance by platinum(iv) prodrugs. Chem. Sci. 2020, 11, 3829-3835. [CrossRef]

14. Chen, Q.; Yang, Y.; Lin, X.; Ma, W.; Chen, G.; Li, W.; Wang, X.; Yu, Z. Platinum(iv) prodrugs with long lipid chains for drug delivery and overcoming cisplatin resistance. Chem. Commun. 2018, 54, 5369-5372. [CrossRef]

15. Quiles, J.L.; Sánchez-González, C.; Vera-Ramírez, L.; Giampieri, F.; Navarro-Hortal, M.D.; Xiao, J.; Llopis, J.; Battino, M.; VarelaLópez, A. Reductive stress, bioactive compounds, redox-active metals, and dormant tumor cell biology to develop redox-based tools for the treatment of cancer. Antioxid. Redox Signal. 2020, 33, 860-881. [CrossRef]

16. Chen, C.; Gao, C.; Yuan, Z.; Jiang, Y. Design, synthesis and biological evaluation of a novel platinum(II) complex possessing bioreductive groups for cancer therapy. Chin. Chem. Lett. 2019, 30, 243-246. [CrossRef]

17. Wang, J.; Wu, G.S. Role of autophagy in cisplatin resistance in ovarian cancer cells. J. Biol. Chem. 2014, 289, 17163-17173. [CrossRef]

18. Ren, J.-H.; He, W.-S.; Nong, L.; Zhu, Q.-Y.; Hu, K.; Zhang, R.-G.; Huang, L.-L.; Zhu, F.; Wu, G. Acquired cisplatin resistance in human lung adenocarcinoma cells is associated with enhanced autophagy. Cancer Biother. Radiopharm. 2010, 25, 75-80. [CrossRef]

19. Cocetta, V.; Ragazzi, E.; Montopoli, M. Mitochondrial involvement in cisplatin resistance. Int. J. Mol. Sci. 2019, 20, 3384. [CrossRef] [PubMed]

20. Marrache, S.; Pathak, R.K.; Dhar, S. Detouring of cisplatin to access mitochondrial genome for overcoming resistance. Proc. Natl. Acad. Sci. USA 2014, 111, 10444-10449. [CrossRef]

21. Garcia-Fernandez, J.; Turiel, D.; Bettmer, J.; Jakubowski, N.; Panne, U.; Rivas García, L.; Llopis, J.; Sánchez González, C.; Montes-Bayón, M. In vitro and in situ experiments to evaluate the biodistribution and cellular toxicity of ultrasmall iron oxide nanoparticles potentially used as oral iron supplements. Nanotoxicology 2020, 14, 388-403. [CrossRef]

22. Pereira, D.I.A.; Bruggraber, S.F.A.; Faria, N.; Poots, L.K.; Tagmount, M.A.; Aslam, M.F.; Frazer, D.M.; Vulpe, C.D.; Anderson, G.J.; Powell, J.J. Nanoparticulate iron(III) oxo-hydroxide delivers safe iron that is well absorbed and utilised in humans. Nanomed. Nanotechnol. Biol. Med. 2014, 10, 1877-1886. [CrossRef]

23. Turiel-Fernández, D.; Gutiérrez-Romero, L.; Corte-Rodriguez, M.; Bettmer, J.; Montes-Bayón, M. Ultrasmall iron oxide nanoparticles cisplatin (IV) prodrug nanoconjugate: ICP-MS based strategies to evaluate the formation and drug delivery capabilities in single cells. Anal. Chim. Acta 2021, 1159, 338356. [CrossRef]

24. Soto-Alvaredo, J.; Blanco, E.; Bettmer, J.; Hevia, D.; Sainz, R.M.; López Cháves, C.; Sánchez, C.; Llopis, J.; Sanz-Medel, A.; MontesBayón, M. Evaluation of the biological effect of Ti generated debris from metal implants: Ions and nanoparticles. Metallomics 2014, 6, 1702. [CrossRef]

25. Roma-Rodrigues, C.; Rivas-García, L.; Baptista, P.V.; Fernandes, A.R. Gene Therapy in Cancer Treatment: Why Go Nano? Pharmaceutics 2020, 12, 233. [CrossRef]

26. Rennick, J.J.; Johnston, A.P.R.; Parton, R. Key principles and methods for studying the endocytosis of biological and nanoparticle therapeutics. Nat. Nanotechnol. 2021, 16, 266-276. [CrossRef]

27. Jayasuriya, A.C.; Darr, A.J. Controlled release of cisplatin and cancer cell apoptosis with cisplatin encapsulated poly(lactic-coglycolic acid) nanoparticles. J. Biomed. Sci. Eng. 2013, 6, 586-592. [CrossRef]

28. Han, Y.; Yin, W.; Li, J.; Zhao, H.; Zha, Z.; Ke, W.; Wang, Y.; He, C.; Ge, Z. Intracellular glutathione-depleting polymeric micelles for cisplatin prodrug delivery to overcome cisplatin resistance of cancers. J. Control. Release 2018, 273, 30-39. [CrossRef]

29. Yang, G.G.; Pan, Z.Y.; Zhang, D.Y.; Cao, Q.; Ji, L.N.; Mao, Z.W. Precisely assembled nanoparticles against cisplatin resistance via cancer-specific targeting of mitochondria and imaging-guided chemo-photothermal therapy. ACS Appl. Mater. Interfaces 2020, 12, 43444-43455. [CrossRef]

30. Velma, V.; Dasari, S.R.; Tchounwou, P.B. Low doses of cisplatin induce gene alterations, cell cycle arrest, and apoptosis in human promyelocytic leukemia cells. Biomark. Insights 2016, 11, 113-121. [CrossRef]

31. Vaisman, A.; Varchenko, M.; Said, I.; Chaney, S.G. Cell Cycle Changes Associated With Formation of Pt-DNA Adducts in Human Ovarian Carcinoma Cells With Different Cisplatin Sensitivity. Cytometry 1997, 27, 54-64. [CrossRef] 